\title{
The relationship between iron deficiency and bone mineral density in young female athletes
}

\author{
Pradita, D.K., *Dieny, F.F., Kurniawati, D.M., Tsani, A.F.A., Widyastuti, N., Fitrianti, \\ D.Y. and Rahadiyanti, A.
}

Department of Nutrition Science, Faculty of Medicine, Universitas Diponegoro, Indonesia

\begin{abstract}
Article history:
Received: 31 January 2020

Received in revised form: 26 March 2020

Accepted: 19 April 2020

Available Online: 30 May 2020
\end{abstract}

\section{Keywords:}

Iron deficiency,

Serum ferritin,

Bone density,

Young female athlete

\section{DOI:}

https://doi.org/10.26656/fr.2017.4(S3).S24

\begin{abstract}
The iron deficiency that occurs in young female athletes can cause a decrease in bone density in three mechanisms, through the process of hydrolysis of procollagen formation, metabolism along with vitamin D and hypoxia. The aimed of this study is to analyze the relationship of iron deficiency with bone density in young female athletes. A crosssectional study design with 70 athletes aged 12-21 years conducted at the BPPLOP Central Java, Salatiga Athletics Club and Athletics and Swimming Club Semarang State University. Iron deficiency was determined by levels of ferritin serum, bone density measured by Bone Densitometer Quantitative Ultrasound, body fat percentage and muscle mass measured by Body Composition Analyzer. Bone-specific Physical Activity Questionnaire was used for physical activity data. Nutrition intakes such as protein, calcium, vitamin D, phosphorus, iron, potassium, magnesium, and sodium was collected by Semi Quantitative-Food Frequency Questionnaire. This study used bivariate analysis with Pearson and Rank-Spearman Correlation Tests and multivariate analysis with Multiple Linear Regression Test. A young female athlete who suffers from iron deficiency is approximately $14.3 \%$. All subjects had normal bone density. Significant relationships were observed between iron deficiency based on serum ferritin $(p=0.044)$ and muscle mass $(p=0.002)$ with bone density on young female athletes. The muscle mass variable had the strongest influence on bone density $\left(\mathrm{p}=0.002\right.$; adjusted $\left.\mathrm{R}^{2}=0.117\right)$. This study showed that iron deficiency and muscle mass are related to bone density, but the other factors that might have an impact on bone density must be considered.
\end{abstract}

\section{Introduction}

Iron deficiency is a progressive condition that develops through three-phase which are iron depletion, iron deficient and iron deficiency anemia. Highly active female and individuals have a higher risk to suffer iron deficiency. A study found that iron deficiency tends to happen to athletes, even up to $52 \%$ in young female athletes, especially in endurance sport (Sandström et al., 2012). This condition is detrimental for athletes because of a decrease in oxygen transport to the muscles, $\mathrm{VO}_{2}$ max, performance and immune system (Saleh et al., 2018). Iron deficiency that caused by high-intensity exercise can occur in several mechanisms, which are the increase of blood loss through urine, decrease of blood flow to the digestive tract which causes bleeding in the digestive tract, increase of sweat production, mechanical trauma and inflammation hence the increase of hepcidin and result in the decrease of iron absorption and erythropoiesis (Muth, 2015). This is consistent with a study which says that high physical exercise can cause a significant increase in IL-6 serum, hepcidin and an increase in ferritin serum as high as $22 \%$ after exercise (Skarpanska et al., 2015). Other factors that can cause iron deficiency are low iron intake in meals and menstruation (Taiyeb et al., 2012). In menstruation period, a woman, either athlete or non-athlete will loss 25-60 ml of blood and 0,4-1 mg iron per day (Kristianti and Wibowo, 2014).

Another problem faced by young female athletes is low bone mineral density or osteopenia. This is consistent with the research in Japan that says $18,6 \%$ of young female athletes with amenorrhea had low bone mineral density (Z score < -1) (Nose-ogura et al., 2018). Exercise affects bone mineral density through bone mechanical loading and hormonal factors (Zaviera, 2008; Maspaitella and Dieny, 2012). Excessive exercise will cause hypothalamic-pituitary-gonadal axis dysfunction 
and low estrogen level that will inhibit the process of homeostatic and bone formation. In addition, hormonal factors also play in bone formation and resorption such as calcium regulating hormones (PTH, calcitriol, calcitonin), estrogen, growth hormone (insulin like growth factor 1), adipocyte-derived hormones (leptin, adiponectin), pancreatic hormones (insulin, amylin, preptin) and the other hormones such as sclerostin dan preadipoctye factor 1/pref-1(U.S. Department of Health and Human Services, 2004; Krishnan and Kalyanaraman, 2019).

Recent studies say that iron deficiency can affect bone mineral density. One of the studies in Korea says that ferritin serum is positively correlated with the lumbar spine (a biomarker of bone mineral density) (Chon et al., 2014). Iron deficiency can affect bone mineral density in three mechanisms, which are through hydroxylation process of procollagen formation, metabolism with vitamin D and hypoxia (Arnett et al., 2003). Iron plays a role in collagen synthesis in which almost $90 \%$ of bone tissue consists of collagen. Iron and P450 cytochrome (hemeprotein enzyme) work together to activate vitamin $\mathrm{D}$ which will regulate metabolism and carry out calcium homeostatic. Iron also plays the role in the synthesis of hemoglobin as an oxygen transporter to prevent hypoxia. Hypoxia can stimulate bone resorption and induce osteoclastogenesis and osteoblastogenesis (Arnett et al., 2003; Shiozawa et al., 2010). Hypoxia condition will induce the formation of hypoxia inducible factor $\alpha$ (HIF-1 $\alpha)$ which can inhibit $\alpha$-ketoglutarate in collagen synthesis (Toxqui and Vaquero, 2015).

Besides all of the factors above, there are other factors that can affect bone mineral density which are internal factors such as genetics, race, gender, age, nutritional statuses such as body mass index, body composition (fat percentage and muscle mass), nutritional intake (protein, calcium, vitamin D, phosphorus, iron, potassium, magnesium, sodium) and lifestyles such as physical activities, caffeine intake, smoking and drugs (Anderson, 2008). According to the explanation, the aim of this study is to analyze the relationship between iron deficiency, fat percentage, physical activity, muscle mass, intake of protein, calcium, vitamin D, phosphorus, iron, potassium, magnesium, sodium and bone mineral density in young female athletes.

\section{Material and methods}

\subsection{Design, location and time}

A cross-sectional study design and this research wasc onducted from May to July at the Balai Pemusatan Pendidikan dan Latihan Olahraga Pelajar (BPPLOP),
Central Java, Salatiga Athletics Club and Athletics and Swimming Club of Semarang State University. This study was approved by the Faculty Ethics Commission of Faculty of Medicine, Universitas Diponegoro No. 343/EC/KEPK/FU-UNDIP/VI/2019.

\subsection{Samplings}

The sample size was estimated using the proportion estimation formula and selected by purposive sampling based on inclusion and exclusion criteria. Subjects are athletes from various sports such as weightlifting, table tennis, martial arts, boxing, rowing, volleyball, sepak takraw, judo, fencing, karate, taekwondo, swimming, sand volleyball, and athletics. The participants were included if they willing to be the subject of research by filling out informed consent, aged 12-21 years, not smoking, not consuming alcohol, not taking bloodboosting drugs, not having menstruation when data collection was done, not having blood donor in the last three months and not consuming sources excessive caffeine (coffee, tea or soft drinks) ( $>3$ medium cups/ day).

\subsection{Data collected}

The dependent variable is bone mineral density and the independent variable is iron deficiency. While confounding variables in this study is the percentage of body fat, muscle mass, physical activity, nutrition intakes such as protein, calcium, vitamin D, phosphorus, iron, potassium, magnesium, and sodium. Data collected in this study are subject identity, ferritin serum, bone mineral density, body fat percentage, muscle mass, physical activity, nutrition intakes such as protein, calcium, vitamin D, phosphorus, iron, potassium, magnesium, and sodium.

Iron deficiency is a condition where iron levels in the body are below normal. Iron deficiency is measured by the levels of ferritin serum in the body. Ferritin serum levels were obtained from a subject's blood sample which was then laboratory tested using the ELISA (Enzyme-linked immunoassays) method. According to the World Health Organization (2011), a person is said to be iron deficient if the ferritin serum level is $<15 \mu \mathrm{g} / \mathrm{L}$.

Bone mineral density (BMD) was measured using portable ultrasound bone densitometer (Sonos 300 Bone Densitometer) at the right side of the calcaneus bone. Tscore was used to categorize subjects into three groups as recommended by the World Health Organization. With those having normal bone density classified as T-score $>$ -1 , the osteopenia group as T-score -1 until -2.5 and osteoporosis classified as T-score $<-2.5$ (Carey and Delaney, 2010). 
Body fat percentage and muscle mass were measured using Tanita DC-430U Dual Frequency Total Body Composition Analyzer. The percentage of body fat is a percentage of fat mass from total body weight. Furthermore, the body fat percentage is categorized according to percentile: $<2=$ underfat, 2 to $85=$ normal, $>85=$ overfat, and $\geq 95=$ obesity (Mccarthy et al., 2006). On the other hand, muscle mass is the total weight of skeletal muscle in the body.

Bone-Specific Physical Activity Questionnaire (BPAQ) BPAQ was used to obtain a comprehensive account of lifetime physical activity. Participants were required to record the type, frequency and years of physical activity involvement. Independent sections for past or pBPA (from one year of age) and current or cBPA (previous 12 months) regular activity (an activity that participant involved) were added to facilitate the analysis of the temporal and age-specific effects of mechanical loading on the skeleton. Past and current results were added to measure total BPAQ score to tBPA. BPAQ score was calculated by using a calculation. The high BPAQ score means the bone receiving high mechanical stimuli during exercise. BPAQ score was categorized based on quartile scores (Weeks and Beck, 2008)

Nutrition intakes such as protein, calcium, vitamin $\mathrm{D}$, phosphorus, iron, potassium, magnesium, and sodium was obtained through the Semi-Quantitative Food Frequency (FFQ) form by interviews. The food photo book is used to minimize bias. The results are processed using the Nutrisurvey program. Intake of protein, calcium, vitamin $\mathrm{D}$, phosphorus, iron, potassium, magnesium, and sodium is calculated on average daily consumption then compared with daily needs. The results are categorized into inadequate $(<80 \%$ of needs), adequate $(80-100 \%$ of needs) and excessive $(>100 \%$ of needs). As for the daily needs of each intake include protein at $1.2 \mathrm{~g} / \mathrm{BW}(\mathrm{kg})$ for endurance sports and $1.4 \mathrm{~g} /$ $\mathrm{BW}(\mathrm{kg})$ for strength sports (Rodriguez and Dimarco, 2009), calcium $1200 \mathrm{mg} /$ day, vitamin $\mathrm{D} 15 \mu \mathrm{g} /$ day, phosphorus $1200 \mathrm{mg}$ /days (12-18 years) and $700 \mathrm{mg} /$ day (>19 years), iron $26 \mathrm{mg}$ /day, potassium $4700 \mathrm{mg} /$ day, magnesium $300 \mathrm{mg} /$ day and sodium $1500 \mathrm{mg} /$ day (Menteri Kesehatan Republik Indonesia, 2013).

\subsection{Data analysis}

All data were analyzed using computer programs. Univariate analysis was used to describe subjects characteristic. The distribution of data for normality was assessed using the Kolmogorov Smirnov test before statistical analysis. The associations of ferritin serum, physical activity (pBPA and tBPA score), protein, calcium, vitamin $\mathrm{D}$, phosphorus, iron, potassium, magnesium and sodium intake with bone mineral density were determined using the Rank Spearman Test. cBPA score, body fat percentage and muscle mass were determined using the Pearson Product Moment test. Furthermore, ferritin serum, body fat percentage, muscle mass, cBPA, pBPA and magnesium intake were analyzed using the Multiple Linear Regression test to find out which variable most influenced the bone mineral density.

\section{Results}

\subsection{Characteristic of subjects}

Subject characteristics, BMD and iron deficiency are shown in Table 1. In this study, most subjects were 1416 years old $(55.7 \%)$. Based on the ferritin serum analyses, $14.3 \%$ of 70 subjects had an iron deficiency. All subjects had a normal BMD, However, there were still four subjects who had negative t-scores. Based on measurements of body fat percentage we found that $20 \%$ of subjects were overfat, $10 \%$ of subjects were obese and the rest were underfat. Most of the subjects (47.1\%) had sufficient total physical activity (tBPA). Meanwhile, subject nutrition intakes (Table 2) showed that only $52.9 \%$ of subjects consumed more protein than needed, while for other nutrients such as calcium, vitamin D, phosphorus, iron, potassium, magnesium, and sodium is less than needed.

Table 1. Subject's characteristic based on various category

\begin{tabular}{lcc}
\hline Category & $\mathrm{n}$ & $\%$ \\
\hline Age & & \\
\hline Early adolescents (10-13 years old) & 2 & 2.9 \\
Middle adolescents (14-16 years old) & 39 & 55.7 \\
Late adolescents (17-21 years old) & 29 & 41.4 \\
\hline Ferritin serum & & \\
\hline Iron deficiency & 10 & 14.3 \\
Normal & 60 & 85.7 \\
\hline BMD & & \\
\hline Normal & 70 & 100 \\
\hline Body fat percentage & & \\
\hline Underfat & 1 & 1.4 \\
Normal & 48 & 68.6 \\
Overfat & 14 & 20 \\
Obesity & 7 & 10 \\
\hline cBPA & & \\
\hline Low & 18 & 25.7 \\
Normal & 33 & 47.1 \\
High & 19 & 27.1 \\
\hline pBPA & 18 & \\
\hline Low & 18 & 25.7 \\
Normal & 34 & 48.6 \\
\hline tBigh & 18 & 25.7 \\
\hline Low & 70.7 \\
Normal & & 100 \\
\hline Amount & & \\
\hline
\end{tabular}


Table 2. Subject's characteristic based on nutrition intakes

\begin{tabular}{|c|c|c|}
\hline Nutrition Intakes & $\mathrm{n}$ & $\%$ \\
\hline \multicolumn{3}{|l|}{ Protein } \\
\hline Inadequate & 23 & 32.9 \\
\hline Adequate & 10 & 14.3 \\
\hline Excessive & 37 & 52.9 \\
\hline \multicolumn{3}{|l|}{ Calcium } \\
\hline Inadequate & 63 & 90 \\
\hline Adequate & 2 & 2.9 \\
\hline Excessive & 5 & 7.1 \\
\hline \multicolumn{3}{|l|}{ Vit D } \\
\hline Inadequate & 68 & 97.1 \\
\hline Adequate & 1 & 1.4 \\
\hline Excessive & 1 & 1.4 \\
\hline \multicolumn{3}{|l|}{ Phosphorus } \\
\hline Inadequate & 41 & 58.6 \\
\hline Adequate & 7 & 10 \\
\hline Excessive & 22 & 31.4 \\
\hline \multicolumn{3}{|l|}{ Iron } \\
\hline Inadequate & 61 & 87.1 \\
\hline Adequate & 2 & 2.9 \\
\hline Excessive & 7 & 10 \\
\hline \multicolumn{3}{|l|}{ Potassium } \\
\hline Inadequate & 55 & 78.6 \\
\hline Adequate & 7 & 10 \\
\hline Excessive & 8 & 11.4 \\
\hline \multicolumn{3}{|l|}{ Magnesium } \\
\hline Inadequate & 40 & 57.1 \\
\hline Adequate & 12 & 17.1 \\
\hline Excessive & 18 & 25.7 \\
\hline \multicolumn{3}{|l|}{ Sodium } \\
\hline Inadequate & 41 & 58.6 \\
\hline Adequate & 11 & 15.7 \\
\hline Excessive & 18 & 25.7 \\
\hline
\end{tabular}

Table 3 describes the minimum, maximum, mean and median values of age, ferritin serum levels, bone mineral density, physical activity, body fat percentage and nutrient intake. The mean value of serum ferritin was $27 \mu \mathrm{g} / \mathrm{L}$ and was still classified as normal. Subjects had a mean bone mineral density of 1.154 which was classified as normal. Meanwhile, the average daily intake of calcium, vitamin $\mathrm{D}$, iron, potassium, magnesium and sodium is still less than daily needs

Based on the correlation test (Table 4), ferritin serum had a relationship with bone density $(\mathrm{p}<0.05)$. But it has a weak correlation $(r=0.241)$ and positive correlation direction which means that the higher the ferritin serum the higher bone mineral density value. As for the confounding variable, only muscle mass had a significant relationship with bone density $(\mathrm{p}<0.05)$.

\subsection{Variables that affect the bone mineral density}

Variables that have $\mathrm{p}$ values $<0.25$ were analyzed by multiple linear regression tests using the backwards method. The correlation test results that ferritin serum, body fat percentage, muscle mass and magnesium intake are qualified. Table 5 describes that muscle mass had the strongest influence on bone mineral density $(\mathrm{p}<0.05)$. The equation obtained is bone density $=-2.053+0.083$ muscle mass. The coefficient of determination value (adjusted $\mathrm{R}^{2}$ ) is 0.117 which means muscle mass affects bone density by $11.7 \%$ while the rest is influenced by other variables not examined.

Table 3. Mean value variables

\begin{tabular}{lccc}
\hline Variables & Min & Max & Mean \pm SD/Median \\
\hline Age (year) & 13 & 21 & $16.3 \pm 1.945^{\mathrm{a}}$ \\
Ferritin serum $(\mu \mathrm{g} / \mathrm{L})$ & 7 & 147 & $27 \pm 22.582^{\mathrm{b}}$ \\
BMD (T score) & -0.5 & 2.8 & $1.154 \pm 0.88^{\mathrm{a}}$ \\
cBPA (score) & 0.765 & 27.519 & $11.367^{\mathrm{a}}$ \\
pBPA (score) & 0.154 & 159.62 & $25.051^{\mathrm{b}}$ \\
tBPA (score) & 1.372 & 86.336 & $18.345 \pm 14.388^{\mathrm{b}}$ \\
Body fat percentage (\%) & 13.1 & 49.8 & $26.57 \pm 6.7542^{\mathrm{a}}$ \\
Muscle mass (kg) & 31.2 & 47.1 & $38.79 \pm 3.8302^{\mathrm{a}}$ \\
Protein intake (g/kg Weight) & 32.5 & 251.4 & $70.1 \pm 41.08^{\mathrm{b}}$ \\
Calcium intake (mg/day) & 50.7 & 1834.1 & $431.9 \pm 366.9^{\mathrm{b}}$ \\
Vit D intake ( $\mu \mathrm{g} /$ day) & 0 & 17.9 & $2.2 \pm 3.07^{\mathrm{b}}$ \\
Phosphorus intake (mg/day) & 234.1 & 2725.2 & $833.85 \pm 462.44^{\mathrm{b}}$ \\
Iron intake (mg/day) & 2.5 & 73 & $7.35 \pm 12.1427^{\mathrm{b}}$ \\
Potassium intake (mg/day) & 570.4 & 8418 & $1937 \pm 1686.03^{\mathrm{b}}$ \\
Magnesium intake (mg/day) & 59 & 820 & $216.9 \pm 155.21^{\mathrm{b}}$ \\
Sodium intake (mg/day) & 194.8 & 3471.1 & $993.05 \pm 669.39^{\mathrm{b}}$ \\
\hline
\end{tabular}


Table 4. Correlation test results

\begin{tabular}{lcc}
\hline Variables & $\mathrm{r}$ & $\mathrm{p}$ value \\
\hline Ferritin serum & 0.241 & $0.044^{*}$ \\
cBPA & 0.072 & 0.553 \\
pBPA & 0.175 & 0.148 \\
tBPA & 0.13 & 0.282 \\
Muscle mass & 0.36 & $0.002^{*}$ \\
Body fat percentage & 0.164 & 0.174 \\
Protein intake & 0.005 & 0.969 \\
Calcium intake & -0.111 & 0.36 \\
Vit D intake & -0.094 & 0.44 \\
Phosphorus intake & -0.076 & 0.533 \\
Iron intake & -0.101 & 0.405 \\
Potassium intake & -0.08 & 0.513 \\
Magnesium intake & -0.143 & 0.239 \\
Sodium intake & -0.136 & 0.263 \\
\hline
\end{tabular}

*significant $(\mathrm{p}<0.05)$

Table 5. Multiple linear regression test result

\begin{tabular}{lccc}
\hline & \multicolumn{3}{c}{ BMD } \\
\cline { 2 - 4 } Variable & ${\text { Adjusted } \mathrm{R}^{2}}^{\mathrm{B}}$ & $\begin{array}{c}\text { (Unstandardized } \\
\text { coefficient) }\end{array}$ & $\mathrm{p}$ \\
\hline Muscle mass & 0.117 & 0.083 & 0.002 \\
Constant & & -2.053 & \\
\hline
\end{tabular}

\section{Discussion}

This study was conducted for 70 young female athletes in several sports such as weightlifting, table tennis, martial arts, boxing, rowing, volleyball, sepak takraw, judo, fencing, karate, taekwondo, swimming, sand volleyball and athletics with an age range between $13-21$ years old with an average age of $16.43 \pm 1.945$. The analysis result found $14.3 \%(\mathrm{n}=10)$ of young female athletes had iron deficiency. This result is lower than Sandstorm et al study which found $52 \%$ of young female athletes had iron deficiency (Sandström et al., 2012). Meanwhile, the mean serum ferritin value of the subject was $27 \mu \mathrm{g} / \mathrm{L}$ and was still within normal limit. Sports or high physical exercise can cause a decrease in iron deposits in the body through the inflammatory response. Intensive physical exercise can increase proinflammatory cytokine level 2 to 3 times higher such as TNF- $\alpha$, IL- $1 \beta$ and IL- 6 which can induce hepcidin synthesis (the main regulator of iron metabolism) which causes a decrease in iron and transferrin level in the body (Peeling, 2010) Moreover, exercise can also cause iron depletion through the increased of blood loss through urine, decreased blood flow to the digestive tract leading to gastrointestinal tract bleeding and increased production of sweat (Muth, 2015). Other factors that can cause iron deficiency are low intake of iron in meals and menstruation (Taiyeb et al., 2012). During the menstrual period, a woman, either athlete or non-athlete will loss
25-60 $\mathrm{ml}$ of blood and 0.4-1 $\mathrm{mg}$ of iron per day (Kristianti and Wibowo, 2014). This study found that subjects suffering from iron deficiency have a low daily iron intake.

All young female athletes have normal bone mineral density. In general, athletes tend to have better bone mineral density compared to non-athletes. This is consistent with a study conducted on 318 groups of young athletes consist of swimming, football, karate, judo, kung fu, basketball athletes and 111 non-athletes groups which showed that athletes mostly had higher bone mineral density in lower limbs and spine. Meanwhile, only karate athletes had lower bone mineral density in the upper spine and whole body compared to the control groups (Maillane-Vanegas et al., 2018). Another study conducted by Nafilah and Fitrianti (2014) also found that $70.3 \%$ of young female suffer osteopenia caused by low physical activities. In this study, almost all of the young female athletes do weight-bearing exercise such as speed walking, jogging, running, jumping and stairs climbing that can increase bone mechanical loading, therefore, providing a positive effect to bone's health and better osteogenic response (Scofield and Hecht, 2012). This consistent with the result of Ahmad et al. (2018) which says that high energy expenditure, low body weight and low bone mechanical loading are factors contributed to low bone mineral density in female athletes. In addition, age also affects bone mineral density, which in this study all the athletes were classified as teenagers. Adolescence is the puberty phase where bone formation and increased bone mineral density occur. Bone formation is higher than bone resorption in adolescence. Age is one of the risk factors of osteoporosis that cannot be changed and increases from 1,4 to 1,8 times in every decade (Anderson, 2008). In addition by the two factors above, bone density is also influenced by hormonal factors such as calcium regulating hormones (PTH, calcitriol, calcitonin), estrogen, growth hormone (insulin like growth factor 1), adipocyte-derived hormones (leptin, adiponectin) and sclerostin and prefadipoctye factor 1/pref-1(U.S. Department of Health and Human Services, 2004; Krishnan and Kalyanaraman, 2019).

Parathyroid hormone functions to maintain calcium levels and stimulate bone remodeling and resorption, calcitriol serves to help the absorption of calcium in the intestine and calcitonin can inhibit bone resorption and keep calcium levels in the plasma from being excessive (U.S. Department of Health and Human Services, 2004). Estrogen hormone has an important role in bone resorption. Estrogen controls osteoclast differentiation by inhibiting the interaction between RANK and RANKL. Also, estrogen can prevent apoptosis and osteoclast death 
so it can directly reduce bone resorption (Khosla et al., 2012). The growth hormone (GH) serves to stimulate the formation of precondrocytes (cartilage). Whereas insulin -like growth factor 1 (IGF-1) functions for the maturation of precondrocytes which will form bone matrix (Locatelli and Bianchi, 2014). Leptin plays a role in bone mineralization and osteoclast signaling (Upadhyay et al., 2015). Adiponectin can induce osteoblast formation through poliferation and differentiation which causes an increase alkaline phosphatase (ALP), osteocalcin (OC), type 1 collagen production, and increased bone matrix minerals (Lubkowska et al., 2014). Pancreatic hormones such as insulin, amylin and preptin derived from pancreatic gland secretions appear to play a role in bone metabolism. Insulin binds to its receptor, insulin binds receptor (InsR), which is osteogenic by increasing collagen synthesis and cell proliferation. Amylin can increase osteoblast cell proliferation thereby causing increased bone formation. Preptin is a hormone secreted by pancreatic $\beta$ cells and is anabolic to bone formation (Faienza et al., 2015).

Sclerostin is a glycoprotein which is directly expressed in osteocyte and acts as an inhibitor of bone formation through Wnt signaling pathway. Sclerostin hormones are more common in young female athletes group compared to young female non-athletes group (Fazeli et al., 2013). In athletes, excessive sclerostin cause problems in bone formation and decreased bone mineral density. How sclerotin can become excessive in athletes is still unknown. But Lombardi et al concluded that high sclerostin in athletes can occur due to age and high impact exercise (Lombardi et al., 2012). Another hormone that can affect bone mineral density is preadipocyte factor-1 (Pref-1). Pref-1 is a hormone from epidermal growth factor-like protein (EGF) which has a role in inhibiting bone-marrow adipocyte and osteoblast differentiation. Bone-marrow adipocyte and osteoblast differentiate from the same progenitor cell called human mesechymal cells (hMSC) which will affect bone formation. Excessive Pref-1 hormone was found in female athletes with hypothalamic amenorrhea and anorexia nervosa (Aronis et al., 2011).

As for the athletes' group, body composition between fat percentage and muscle mass must be monitored. An athlete must have higher muscle mass than fat mass. It is said that high muscle mass will increase strength and speed, therefore, enhanced the performance and cardiorespiratory endurance in athletes. On the contrary, a high body fat percentage in an athlete can reduce cardiorespiratory endurance, slow movement, muscle endurance, muscle strength and elasticity hence disturb the performance (Malina and Getihner, 2011). Moreover, fat percentage and muscle mass also contribute to risk factors for bone mineral density. Body fat percentage has a direct impact on bone mineral density and stimulate bone by secreting active hormone from the pancreatic beta cell (insulin, amylin and preptin) and adipose (estrogen, adiponectin and leptin). Low body fat percentages are associated with low leptin level. Low leptin level can increase bone resorption and decrease bone mineral density (Jeddi et al., 2015). This study found $68.6 \%$ of subjects had normal body fat percentage and normal bone mineral density. A study conducted by Kim et al. (2016) show that there is no relationship between fat percentage and all bone measurements (total hip and femoral neck). Lee et al also found that lean body mass, muscle mass and fat mass were related to bone mineral density (lumbar spine, femoral neck), only fat percentage that was not related to bone mineral density (Lee et al., 2012). According to previous studies, this study also did not found any relationship between fat percentage and bone mineral density in young female athletes.

Subject's physical activities were measured using BPAQ (Bone Specific Physical Activity Questionnaire) form. BPAQ is a specially designed questionnaire related to bone strength and has three components in which each component predict bone strength in each aspect. Current physical activity or cBPA can predict bone strength in the hips and spine. And past-activity or pBPA can predict bone strength in heels (Weeks and Beck, 2008). Theoretically, physical activities especially weightbearing exercise such as speed walking, jogging, running, jumping, and stairs climbing that are carried out intensively and continuously can increase bone mechanical loading that will give a positive effect on bone health and better osteogenic response (Scofield and Hecht, 2012). This is consistent with Ahmad's study which said low bone mechanical loading is one of the risk factors of low bone mineral density in female athletes (Ahmad et al., 2018). But according to the analysis result of three components of the BPAQ's, it showed no correlation with bone mineral density. A study by Kim et al. (2016) also showed the same result that there was no correlation between BPAQ and bone mineral density (seen from the hips and femoral neck bones). Different results were found from Weeks and Beck (2008) that cBPA is a significant predictor of bone mineral density (seen from the femoral neck, lumbar spine and whole body). This inconsistent result may be caused by the various bone measurement devices that were used (DXA and QUS) and different parts of the bone that were being measured (heels, hips, backbones, femoral neck).

Protein intake of most subjects was classified as 
excessive intake, while the micronutrient intake was classified as inadequate such as calcium, vitamin D, phosphorus, iron, potassium, magnesium and sodium. This results of this study are similar to study that was conducted on 40 female athletes aged 18-22 years old in America which showed that average intake of energy, magnesium, calcium, potassium and sodium during the beginning of the season until the end of match season is still below the nutritional intake recommendation. The athletes' nutritional intake, which is still largely below their need was probably caused by their lack of knowledge in choosing and implementing appropriate dietary habits (Nepocatych et al., 2017). Weight limiting program applied in several sports is also one of the contributing factors causing low nutritional intake in athletes. The correlation test results also showed that none of the nutrients had a significant relationship with bone density. According to Rita's research, there is no relationship between vitamin and mineral intake and calcaneus bone mineral density in women. The significance of this relationship is not due to the abundance of minerals and vitamins that play a role in the formation of bone matrix. Lack of supply of certain nutrients results in decreased growth and bone density (Ramayulis et al., 2011). Besides, most bone density is determined by genetic factors which contribute to about $50 \%$ of the total bone density variation in the entire population including adolescents. The peak bone density of $80 \%$ of adolescents was influenced by genetic factors (Schtscherbyna et al., 2013).

Bivariate analysis found that only ferritin serum and muscle mass correlated to bone mineral density in young female athletes. It is consistent with a study by Chon et al. (2014) in Korea that said ferritin serum which indicates iron deposits in the liver was positively correlated to the lumbar spine (one of bone mineral density biomarker). Ferritin serum is strongly related to iron deposits in the body. There is no study nor journal that explain the effect of ferritin serum on bone mineral density, therefore ferritin is defined as iron deficiency. Theoretically, iron plays a major role in bone metabolism through three mechanisms, which are through the process of hydroxylation of procollagen formation, metabolism with vitamin $\mathrm{D}$ and hypoxia. Procollagen formation requires iron for the glycosylation forming triple helix collagen process works perfectly. Furthermore, procollagen will be synthesized to form bone tissue (Proff and Römer, 2009; Toxqui and Vaquero, 2015). Iron through P450 cytochrome (hemeprotein enzyme) works to activate vitamin D into 25-hydroxyvitamin D (25OHD) in the liver and 1,25dihydroxy vitamin $\mathrm{D}(1,25 \mathrm{OHD})$ in the kidneys. After that, the hydroxylation process will take place to regulate active vitamin $\mathrm{D}$ to play a role in calcium homeostatic process. $1,25 \mathrm{OHD}$ plays a role in calcium absorption in the intestine, phosphorus absorption, phosphate reabsorption in kidneys and calcium and phosphate release from the bones (Sakaki et al., 2005; Holick and Chen, 2008; Holick, 2009). Iron also plays a role as an oxygen transporter to prevent hypoxia. Hypoxia stimulates bone resorption and induces osteoclastogenesis and osteoblastogenesis (Arnett et al., 2003; Shiozawa et al., 2010). Hypoxic condition will induce hypoxia inducible factor $\alpha$ (HIF-1 $\alpha$ ) formation that can inhibit $\alpha$-ketoglutarate in collagen synthesis. Hypoxic condition can also cause acidosis that will induce bone resorption to release phosphate and restore acid-base balance in the extracellular fluid (Toxqui and Vaquero, 2015). Analysis of the result showed that ferritin serum has a positive correlation with the bone mineral density which means the higher the ferritin serum, the better the bone mineral density.

Besides ferritin serum, there is another variable that has a correlation to the bone mineral density which is muscle mass $(\mathrm{p}<0.05)$. According to a study conducted by Rafael Luiz de Marco et al. (2019), muscle mass is one determinant factor that affects the bone mineral density in both young men and female. Muscle mass plays an important role in maintaining cardiorespiratory endurance performance and athlete's bone mineral density. Muscle mass can affect bone mineral density by mechanical pathway (mechanotransduction) and metabolic pathway. Muscles and bones have cells and hormones which is called bone-muscle unit such as osteocyte, ostokines (TGF1, OCN, PGE-2, FGF23), osteoinhibitor and osteoinducer. There are also other tissues that play a role in the metabolism of muscle mass and bone such as cartilage, adipose tissue and tendons. Regular exercise by athletes will strengthen muscles by putting pressure on the bone and activate bone metabolism through signaling pathways, therefore produce many osteocytes and increase bone mineral density (Tagliaferri et al., 2015). In conclusion, regular exercise will increase muscle mass which will put more pressure on the bone and enhanced bone mineral density. This theory is similar to a study result which says muscle mass has a positive correlation with the bone mineral density which can be interpreted that the higher the muscle mass, the stronger the bones.

\section{Conclusion}

As many as $14.3 \%$ of female athletes suffer iron deficiency. Ferritin serum and muscle mass had a significant relationship with bone mineral density. The results of multivariate analysis showed that muscle mass was the most influential variable on the bone density of young female athletes 


\section{Conflict of interest}

The authors declare no conflict of interest on this research.

\section{Acknowledgments}

The authors would like to thank the subjects at the Balai Pemusatan Pendidikan dan Latihan Olahraga Pelajar (BPPLOP) Central Java, Salatiga Athletics Club and Athletics and Swimming Club of Semarang State University. This study was funded by Research and Development Grants of the Medical Faculty, Universitas Diponegoro 2019.

\section{References}

Ahmad, N.S., Hamid, M.S.A., Cheong, J.P.G. and Hamzah, S.H. (2018). Bone mineral density and associated risk factors among female athletes: a cross -sectional study. Sains Malaysiana, 47(1), 123-129. https://doi.org/10.17576/jsm-2018-4701-15

Anderson, J.J.B. (2008). Nutrition and bone health. In Mahan, K. and Raymond, J. (Eds). Krause's Food and Nutrition Therapy. 12th ed., p. 614-633. Philadelphia, USA: Elsevier.

Arnett, T.R., Gibbons, D.C., Utting, J.C., Orriss, I.R., Hoebertz, A., Rosendaal, M. and Meghji, S. (2003). Hypoxia is a major stimulator of osteoclast formation and bone resorption. Journal of Cellular Physiology, 196(1), 2-8. https://doi.org/10.1002/ jcp. 10321

Aronis, K.N., Kilim, H., Chamberland, J.P., Breggia, A., Rosen, C. and Mantzoros, C.S. (2011). Preadipocyte factor-1 levels are higher in women with hypothalamic amenorrhea and are associated with bone mineral content and bone mineral density through a mechanism independent of leptin. The Journal of Clinical Endocrinology and Metabolism, 96(10), 1634-1639. https:// doi.org/10.1210/jc.2011-0600

Carey, J.J. and Delaney, M.F. (2010). T-Scores and ZScores. Cilinical Reviews in Bone Mineral Metabolism, 8, 113-121. https://doi.org/10.1007/ s12018-009-9064-4

Chon, S.J., Choi, Y.R., Roh, Y.H., Yun, B.H., Cho, S., Choi, Y.S. Choi, Y.S., Lee, B.S. and Seo, S.K. (2014). Association between levels of serum ferritin and bone mineral density in Korean premenopausal and postmenopausal women: KNHANES 20082010. PloS one, 9(12), e114972. https:// doi.org/10.1371/journal.pone.0114972

Faienza, M.F., Luce, V., Ventura, A., Colaianni, G.,
Colucci, S., Cavallo, L., Grano, M. and Brunetti, G. (2015). Skeleton and glucose metabolism: a bonepancreas loop. International Journal of Endocrinology, 2015, 758148. https:// doi.org/10.1155/2015/758148

Fazeli, P.K., Ackerman, K.E., Pierce, L., Guereca, G., Bouxsein, M. and Misra, M. (2013). Sclerostin and Pref-1 have differential effects on bone mineral density and strength parameters in adolescent athletes compared with non athletes. Osteoporosis International, 24, 2433-2440. https:// doi.org/10.1007/s00198-013-2353-2

Holick, M.F. (2009). Vitamin D Status : Measurement, Interpretation, and Clinical Application. AEP, 19(2), 73-78. https://doi.org/10.1016/ j.annepidem.2007.12.001

Holick, M.F. and Chen, T.C. (2008). Vitamin D deficiency: a worldwide problem with health. American Journal Clinical Nutrition, 87(4), 10801086. https://doi.org/10.1093/ajcn/87.4.1080S

Jeddi, M., Dabbaghmanesh, M.H. and Omrani, G.R. (2015). Relative importance of lean and fat mass on bone mineral density in Iranian children and adolescents. International Journal of Endocrinology and Metabolism, 13(3), 1-9. https://doi.org/10.5812/ ijem.25542v2

Khosla, S., Oursler, M.J. and Monroe, D.G. (2012). Estrogen and the skeleton. Trends in Endocrinology and Metabolism, 23(11), 576-581. https:// doi.org/10.1016/j.tem.2012.03.008

Kim, S., So, W.Y., Kim, J. and Sung, D.J. (2016). Relationship between bone-specific physical activity scores and measures for body composition and bone mineral density in healthy young college women. Plos One, 11(9), 1-10. https:// doi.org/10.1371/journal.pone.0162127

Krishnan, S. and Kalyanaraman, V. (2019). Bone health in obesity and the cross talk between fat and bone. In Bagchi, D. (Ed.) Global Perspectives on Childhood Obesity. 2nd ed., p. 247-253. USA: Academic Press. https://doi.org/10.1016/B978-0-12-812840-4.000190

Kristianti, S. and Wibowo, T.A. (2014). Hubungan Anemia dengan Siklus Menstruasi pada Remaja Putri di SMA Negeri 1 Imogiri, Bantul, Yogyakarta Tahun 2013. Jurnal Studi Pemuda, 3(1), 33-38. [In Bahasa Indonesia].

Lee, S.-M., Wang, J.-S., Park, S.-K., Kim, H.-R., Ko, J.H., Oh, Y.-J., Yoon, H.-R. and Kim, J.S. (2012). A Study of Correlation among Bone Mineral Density, Body Composition and Body Circumference on 20's Women. Journal of International Academy of 
Physical Therapy Research, 3(1), 383-390. https:// doi.org/10.5854/JIAPTR.2012.3.1.383

Locatelli, V. and Bianchi, V.E. (2014). Effect of GH/IGF -1 on bone metabolism and osteoporsosis. International Journal of Endocrinology, 2014, 235060. https://doi.org/10.1155/2014/235060

Lombardi, G., Colombini, A. and Mariotti, M. (2012). Sclerostin concentrations in athletes: Role of load and gender. Journal of Biological Regulators and Homeostatic Agents, 20(1), 157-163.

Lubkowska, A., Dobek, A., Mieszkowski, J., Garczynski, W. and Chlubek, D. (2014). Adiponectin as a biomarker of osteoporosis in postmenopausal women: controversies. Disease Markers, 2014, $975178 . \quad \mathrm{https} / / /$ doi.org/10.1155/2014/975178

Luiz-de-Marco, R., Kemper, H., Agostinete, R.R., Werneck, A.O., Maillane-Vanegas, S., Faustino-daSilva, Y.D.S., Exuperio, I. and Fernandes, R.A. (2019). Sports participation and muscle mass affect sex-related differences in bone mineral density between male and female adolescents: A longitudinal study. Sao Paulo Medical Journal, 137, 75-81.

3180.2018.031040119

Maillane-Vanegas, S., Agostinete, R.R., Lynch, K.R., Ito, I.H., Luiz-de-Marco, R., Rodrigues-Junior, M.A., Turi-Lynch, B.C. and Fernandes, R.A. (2018). Bone mineral density and sports participation. Journal of Clinical Densitometry. [Accepted]. https://doi.org/10.1016/ j.jocd.2018.05.041

Malina, R. and Getihner, C. (2011). Body composition of young athletes. American Journal of Lifestyle Medicine, 5(3), 262-278. https:// doi.org/10.1177/1559827610392493

Maspaitella, M. and Dieny, F.F. (2012). Hubungan asupan kalsium dan fosfor, indeks massa tubuh, persen lemak tubuh, kebiasaan olahraga, usia awal menstruasi dengan kepadatan tulang pada remaja putri. Journal of Nutrition College, 1(1), 229-240. [In Bahasa Indonesia].

McCarthy, H.D., Cole, T.J., Fry, T., Jebb, S.A. and Prentice, A.M. (2006). Body fat reference curves for children. International Journal of Obesity, 30(4), 598-602. https://doi.org/10.1038/sj.ijo.0803232

Menteri Kesehatan Republik Indonesia. (2013). Peraturan Menteri Kesehatan Republik Indonesia Nomor 75 Tahun 2013 Tentang Angka Kecukupan Gizi Yang Dianjurkan Bagi Bangsa Indonesia. Indonesia: Menteri Kesehatan Republik Indonesia. [In Bahasa Indonesia].
Muth, N.D. (2015). Nutrition Strategies for Optimal Athletic Performance. In Sports nutrition for health professionals. 1st ed., p. 134-143. New York: NY McGraw-Hill Education LLC.

Nafilah and Fitranti, D.Y. (2014). Hubungan Indeks Massa Tubuh (IMT), persen lemak tubuh, asupan zat gizi dan aktivitas fisik dengan kepadatan tulang pada remaja putri. Journal of Nutrition College, 3(4), 680 -688. [In Bahasa Indonesia].

Nepocatych, S., Balilionis, G. and Neal, E.K.O. (2017). Analysis of Dietary Intake and Body Composition of Female Athletes over a Competitive Season. Montenegrin Journal of Sport Medicine Science, 6 (2), 57-65. mjssm.2017.09.008

Nose-Ogura, S., Yoshino, O., Dohi, M., Kigawa, M., Harada, M., Kawahara, T., Osuga, Y. and Saito, S. (2018). Low Bone Mineral Density in Elite Female Athletes With a History of Secondary Amenorrhea in Their Teens. Clinical Journal of Sport Medicine [Accepted]. https://doi.org/10.1097/ JSM.0000000000000571

Peeling, P. (2010). Exercise as a mediator of hepcidin activity in athletes. European Journal of Applied Physiology, 110, 877-883. https://doi.org/10.1007/ s00421-010-1594-4

Proff, P. and Römer, P. (2009). The molecular mechanism behind bone remodelling: a review. Clinical Oral Investigations, 13(4), 355-362.

Ramayulis, R., Pramantara, D.I. and Pangastuti, R. (2011). Asupan vitamin , mineral, rasio asupan kalsium dan fosfor dan hubungannya dengan kepadatan mineral tulang kalkaneus wanita. Jurnal Gizi Klinik Indonesia, 7(3), 115-122.

Steinmuller, P.L., Meyer, N.L., Kruskall, L.J., Manore, M.M., Rodriguez, N.R., Macedonio, M., Bird, R.L. and Berning, J.R. (2009). American Dietetic Association standards of practice and standards of professional performance for registered dietitians (generalist, specialty, advanced) in sports dietetics. Journal of the Academy of Nutrition and Dietetics, 109(3), 544-552. https://doi.org/10.1016/ j.jada.2009.01.015

Sakaki, T., Kagawa, N., Yamamoto, K. and Inouye, K. (2005). Metabolism of vitamin D3 by cytochromes P450. Front Bioscience, 10(1), 119-134. https:// doi.org/10.2741/1514

Saleh, M.A., Abdo, A.S., Eldesouky, R.S., El-Awady, M.A. and Shaker, M. (2018). Epidemiological study of iron deficiency anemia among youth female athletes in Kuwait. Biomedical Journal of Scientific and Technical Research, 8(4), 6640-45. https:// 
doi.org/10.26717/BJSTR.2018.08.001689

Sandström, G., Börjesson, M. and Rödjer, S. (2012). Iron deficiency in adolescent female athletes - is iron status affected by regular sporting activity?. Clinical Journal of Sport Medicine, 22(6), 495-500. https:// doi.org/10.1097/JSM.0b013e3182639522

Schtscherbyna, A., Ribeiro, B.G. and Farias, M.L.F.D. (2013). Bone Health, Bone Mineral Density and Sports Performance. In Bagchi, D., Nair, S., and Sen, C.K. (Eds.) Nutrition and Enhanced Sports Performances, p. 75-80. San Diego, USA: Elsevier. https://doi.org/10.1016/B978-0-12-396454-0.000072

Scofield, K.L. and Hecht, S. (2012). Bone health in endurance athletes: runners, cyclists and swimmers. Current Sports Medicine Reports, 11(6), 328-34. https://doi.org/10.1249/JSR.0b013e3182779193

Shiozawa, Y., Jung, Y., Ziegler, A.M., Pedersen, E. A., Wang, J., Wang, Z., Song, J., Wang, J., Lee, C.H., Sud, S., Pienta, K.J., Krebsbach, P.H. and Taichman, R.S. (2010). Erythropoietin Couples Hematopoiesis with Bone Formation. Plos One, 5(5), e10853. https://doi.org/10.1371/journal.pone.0010853

Skarpańska-Stejnborn, A., Basta, P., Trzeciak, J. and Szcześniak-Pilaczyńska, Ł. (2015). Effect of intense physical exercise on hepcidin levels and selected parameters of iron metabolism in rowing athletes. European Journal of Applied Physiology, 115, 345351. https://doi.org/10.1007/s00421-014-3018-3

Tagliaferri, C., Wittrant, Y., Davicco, M.J., Walrand, S. and Coxam, V. (2015). Muscle and bone, two interconnected tissues. Ageing Research Reviews, 21, 55-70 https://doi.org/10.1016/ j.arr.2015.03.002

Taiyeb, A.M., Hammado, N. and Nawir, N. (2012). Pengaruh suplementasi zat besi $(\mathrm{Fe})$ terhadap kadar ferritin darah atlet wanita saat menstruasi. Jurnal Bionature, 13(1), 48-51. [In Bahasa Indonesia].

Toxqui, L. and Vaquero, M.P. (2015). Chronic Iron Deficiency as an Emerging Risk Factor for Osteoporosis: A Hypothesis. Nutrients, 7(4), 23242344. https://doi.org/10.3390/nu7042324

U.S. Department of Health and Human Services. (2004). Bone Health and Osteoporosis: A Report of the Surgeon General., p. 25-29. Rockville, MD, U.S.: U.S. Department of Health and Human Services, Office of the Surgeon General.

Upadhyay, J., Farr, O.M. and Mantzoros, C.S. (2015). The role of leptin in regulating bone metabolism. Metabolism, 64(1), 105-113. https://doi.org/10.1016/ j.metabol.2014.10.021

Weeks, B.K. and Beck, B.R. (2008). The BPAQ : A bone -specific physical activity assessment instrument. Osteoporosis International, 19, 1567-77. https:// doi.org/10.1007/s00198-008-0606-2

World Health Organization. (2011). Serum ferritin concentrations for the assessment of iron status and iron deficiency in populations. Geneva, Rome: Vitamin and Mineral Nutrition Information System.

Zaviera, F. (2008). Osteoporosis: deteksi dini, penanganan, dan terapi praktis. Yogyakarta, Indonesia: Ar-Ruzz Media. [In Bahasa Indonesia]. 